\title{
Anti-müllerian hormone, inhibin B and antral follicle count as markers of premature ovarian failure in women with type I diabetes mellitus
}

\author{
Alshimaa A . Abd Elatif* Sabah I . Abd Elreheem**, \\ Amany M. E . Abd Elmegeed ${ }^{* *}$, Hoda Mahmoud Abd El Wahab*** \\ Gynecology and obstetric*, Clinical pathology**, Radiodiagnostic Departments, Al \\ Azhar University, Faculty of Medicine for Girls.
}

\begin{abstract}
Objective:

To evaluate the different markers of ovarian reserve (AMH-Inhibin B, FSH and antral follicle count (AFC) in insulin dependent diabetes mellitus ( IDDM).

\section{Methods:}

We studied 30 patients with IDDM as study groups (10cases $>32$ years group IV and 20 cases $\leq 32$ years group II) and 20 healthy women as control groups ( 8 cases $>32$ years group III and 12 cases $\leq 32$ years group I. Serum levels of FSH, LH, inhibin B and AMH were measured at (days 1-7) of menstrual cycle and AFC was done by trans vaginal ultrasound.
\end{abstract}

\section{Results:}

AMH levels were lower in IDDM patients than in controls > 32 years $(2.35 \pm 2.2$ versus $7.79 \pm 1.73 \mathrm{p} 0.000$ ). Also IDDM groups showed lower levels of inhibin B. While there is no difference in the levels of FSH .. AFC is valuable for the diagnoses of premature ovarian failure in IDDM.

\section{Conclusion:}

Compared with FSH (AMH and inhibin B) are more valuable for the diagnosis of premature ovarian aging in IDDM patients which developed earlier decline in the ovarian follicle pool compared with the healthy women and also AMH is more valuable than AFC for detection of premature ovarian failure in IDDM.

\section{Introduction}

Menopause is defined according to the world health organization classification as condition of absence of spontaneous menstrual bleeding for more than 12 months. The most frequently applied definition of premature ovarian failure (POF) is the spontaneous absence of menses for at least 4 months in combination with FSH levels exceeding 40 IU/liter before age 40 years. This condition occurs in approximately $1 \%$ of the female population (Coulam et al., 1986).

Menopause is an event that is associated with the exacerbation of several diseases and a decrease in bone mass (Martin and Manson, 2008). These abnormalities may be especially detrimental for woman with type 1 diabetes mellitus (IDDM) who also experience menopause at a younger age (8 years earlier in women with DMI as compared with their sisters) (Conder and Cassoral, 2009,SnellBergeon et al., 2008).

Anti-müllerian hormone (AMH and inhibin $\mathrm{B}$ are member of the transforming growth factor B super family and both are expressed by the granulosa cellsof the ovary.

Circulating levels of AMH and inhibin B are correlated with primordial follicle recruitment, suggesting that they may be potential clinical markers for ovarian reserve. 
Inhibin B is a glycoprotein hormone produced mainly by granulosa cells of the ovary in early folliculogenesis. It selectively suppresses the secretion of pituitary FSH and has local paracrine actions in gonads.

. AMH determination has been proposed in clinical practice for the prediction of ovarian reserve because it signals pool of inactive and initially growing follicles, it means, the stock of primordial follicles. In other words, AMH is considered to be a marker that can be used to estimate the quantity and activity of retrievable follicle units in early stages of maturation, thus more reliable for the prediction of ovarian reserve (Sowers et al., 2008).

$\mathrm{AMH}$ as compared to FSH, inhibin-B and $\mathrm{E}_{2}$, has the advantage of reduced variability of its serum concentrations along the menstrual cycle, with consequent credibility, uniformity of evaluation and malleability regarding the time of determination.

There are recent reports of AMH as an accurate noninvasive method for determining ovarian follicle reserve and reproductive aging. Women with IDDM have prematurely aging ovaries, as demonstrated by an early decline in the levels of AMH and inibin B (Soto et al., 2009),

Sowers et al. (2008) observed that serum AMH levels began to decline 10 years before the final menstruation however levels of estradiol $\left(\mathrm{E}_{2}\right)$ and FSH were normal until a couple of years before the cessation of menses.

The mean AMH only declines after about age $30( \pm 3)$ years, so AMH can only be regulated as being correlated with declining ovarian reserve after this age.

Likewise, studies of early follicular inhibin $\mathrm{B}$ are thought to be an indicator of ovarian aging, but a single-time inhibin $B$ value is more difficult to interpret because it may be influenced by cycle phase as well as body mass and perhaps ethnicity (Freeman et al., 2005).

FSH is secreted by the B-cells of the anterior pituitary under the control of the gonadotrophin releasing hormone produced in the hypothalamus. FSH facilitates the development and maintenance of gonadal tissues, which synthesize and secrete steroid hormones. Circulating levels of FSH are controlled by a negative feedback mechanism on the hypothalamus by steroidal hormones (Burger et al., 2007).

In menopause, with diminished ovarian function, there is a resulting decrease in estradiol secretion. Due to the lack of a negative feedback effect, with diminished estradiol, the circulating FSH levels become significantly increased (Mary et al., 2008).

Scheffer et al. (1999) demonstrated that the number of primordial follicles in the ovary as published by (Faddy and Gosden, 1996). Correlated well with the number of growing follicles, counted by trans-vaginal sonography in the early follicular phase so decreasing size of the antral follicles cohort with age is a reflection of the decreasing primordial follicle pool. They used this principle to measure ovarian reserve, defined as the total number of follicles, which can be stimulated under maximal ovarian stimulation with FSH.

(Hendriks et al., 2005) published a metaanalysis on the AFC as a predictor for poor ovarian response and concluded that AFC is an adequate test for the prediction of poor ovarian response comparing to basal FSH.

This study was conducted to evaluate the different markers of ovarian reserve (AMHInhibin B , FSH and antral follicle count (AFC) in insulin dependant diabetes mellitus ( IDDM).

Subjects and Methods

The present study included 30 patients with IDDM as a study group and 20 healthy women as a control group selected from out-patient Gynecology clinic at Al-Zahraa University Hospital from Sept 2009-April 2010. . Patients with IDDM included in this study fulfilled the following inclusion criteria( women younger than 40 years, not pregnant, did not obtain hormonal therapy or any drug known to affect ovarian function for at least 6 months prior to enrollment. did not undergo radiotherapy or chemotherapy or ovarian surgery were diagnosed with IDDM before 30 years of age and the duration of disease was at least forl year. : Women were excluded if they 
were ( Type 2 D.M or other types of D.M .If they have liver, renal. thyroid and. Genetic diseases )

\section{Study Protocol}

Full history taking including menstrual history. General examination (height and weight).

- Patient mean age was 42 years (Range $20-40$ years) SD 2-1).

- Mean BM1 was $26.5 \pm 5.3 \mathrm{~kg} / \mathrm{m}^{2}$.

- Menstrual cycles were considered as irregular if they were longer than 35 days or shorter than 21 days or when the length difference between two successive cycles was greater than 2 days (Burger et al., 2005).

Antral follicle count (AFC) was defined as the total number of visible round or oval, intra ovarian transonic structures with diameter between 2 and $10 \mathrm{~mm}$.

Low AFC cut off was set as less than five follicles because this number is associated with poor response and significantly lower rate of pregnancies in invitro fertilization IVF (Bancsi et al., 2004).

AFC were measured using $2 \& 3 \mathrm{D}$ ultrasound imaging with the $7.5 \mathrm{MHZ}$ endovaginal probe (Kertz-voluson 530D or medison V20). The patients were examined at early follicular phase 1-7 days of menstruation once the ovary was located the observer used the transducer to scroll through the ovary in two planes, longitudinal and transverse and observe the antral follicles. Each antral follicle was then identified in turn until the whole ovary had been analyzed. Antral follicle size was measured by taking the mean of two perpendicular diameters. Then count the number of follicles (Fig. 1, $2 \& 3$ ). Then 3D mode was activated and the measurement and counting of antral follicle were repeated to obtain accurate antral follicles counting. The same process was repeated for the contralateral ovary. If one or both ovaries could not be visualized, the AFC was marked as not visible.

Sex $\mathrm{ml}$ of venous blood were withdrawn under aseptic conditions from both groups of women during the follicular phase (days 1-7) for the measurement of $\mathrm{AMH}$, inhibin $\mathrm{B}$, gonadotrophins.

F.S.H and LH were done by immulite 1000 auto analyzer.Kits supplied from Siemens,
Germany,(catalog number LKLH1) with analytical sensitivity $0.1 \mathrm{mIU} / \mathrm{ml}$ for both. FSH \& LH is a solid phase, two-site chemiluminescent immunometric assay. (The solid phase is a polystyrene bead enclosed within a test unit, is coated with a monoclonal murine anti LH or FSH antibody. The patient specimen is added to the test unit containing the coated bead. An alkaline phoshatase conjugated to polycolonal goat anti - LH or FSH is also added to the test unit.After the wash and incubation steps, chemiluminescent substrate undergoes hydrolysis in the presence of alkaline phoshatase .The photon output as measured by the luminometer is related to the presence of LH or FSH in the sample).

\section{AMH Assay}

Serum AMH was assayed using active MIS / AMH E1ISA kit (diagnostic system laboratories, INC. (ABeckman coulter company, DSL- 10- 14400) For direct measurement of $\mathrm{AMH}$ in human serum. The analytical sensitivity is $0.006 \mathrm{ng} / \mathrm{ml}$.Intra and inter assay coefficient of variation is between 3.3 and $4.6 \%$ and between 6.7 and $8.0 \%$ respectively.

The ACTIVE MIS/AMH ELISA is an enzymatically amplified two-site immunoassay. In the assay, standards, controls and samples are incubated in microtitration wells which have been coated with antiMIS/AMH antibody. After incubation and washing, anti-MIS/AMH detection antibody labeled with biotin is added to each well. After a second incubation and washing step, streptavidinhorseradish peroxidase (HRP) is added to the wells. After a third incubation and washing step, the substrate tetramethylbenzidine (TMB) is added to the wells.

Lastly, an acidic stopping solution is added. The degree of enzymatic turnover of the substrate is determined by dual wavelength absorbance measurement at $450 \mathrm{~nm}$ and between 600 and $630 \mathrm{~nm}$. The absorbance measured is directly proportional to the concentration of MIS/AMH in the samples. A set of MIS/ AMH standards is used to plot a standard curve of absorbance versus MIS/AMH concentration. The MIS/AMH 
concentrations in the samples can then be calculated from this standard curve.

\section{Inhibin B Assay}

Serum inhibin B was assayed using active inhibin B ELISA kits (diagnostic systems laboratories, INC.Corporate, head quarters, USA DSL- 10-84100) .The analytical sensitivity is $7 \mathrm{pg} / \mathrm{ml}$. Intra assay and inter assay coefficient of variation is between 3.5 and $5.6 \%$ and between 6.2 and $7.6 \%$ respectively

The DSL-10-84100 ACTIVE® Inhibin B ELISA is an enzymatically amplified twosite two-step sandwich-type immunoassay. In the assay, Standards, Controls and unknown serum samples are incubated in microtitration wells, which have been coated with anti-inhibin beta B subunit antibody. After incubation and washing, the wells are incubated with biotinylated antiinhibin alpha-subunit detection antibody and the immunoreaction monitored by subsequent addition of streptavidin labeled with enzyme horseradish peroxidase (HRP). After a third incubation and washing step, the wells are incubated with the substrate tetramethylbenzidine (TMB) .

An acidic stopping solution is then added and the degree of enzymatic turnover of the substrate is determined by dual wavelength absorbance measurement at 450 and 620 $\mathrm{nm}$. The absorbance measured is directly proportional to the concentration of inhibin B present. A set of inhibin B Standards is used to plot a standard curve of absorbance INHIBIN B EL ISA DSL-10-84100

Statistical analysis:

- Data was analyzed by Microsoft Office 2003 (excel) and Statistical package for Social Science (SPSS) version 16.

- Parametric data was expressed as mean $\pm \mathrm{SD}$, and non parametric data was expressed as number and percentage of the total.

- Comparing the mean \pm SD of 2 groups was done using the student's $t$ test.

- Comparing more than two groups was performed using the Analysis of Variance (ANOVA).

- Measuring the mutual correspondence between two values was done using the spearman correlation coefficient.

$\mathrm{P}$ value $>0.05$ is considered non-significant $\mathrm{P}$ value $<0.05$ is considered significant

$\mathrm{P}$ value $<0.01$ is considered highly significant.

\section{Results}

Women with IDDM their age > 32 years (ranged from 32- 40 with mean \pm SD 36.2 \pm 3.7 group IV and their number was 10 .

Women with (IDDM) their age $\leq 32$ years ranged from 20 to 32 years with mean \pm SD $21.8 \pm 4.0$ group II. Compared to matched controls (20). These control groups were classified into 2 groups.

Healthy women their age were $>32$ years with mean \pm SD $37.4 \pm 3.9$ and their number were 8 women (group III).

healthy women their age were $\leq 32$ years with mean $\pm 29.2 \pm 7.8$ and their number were 12 women group (group I).

The body mass index (BMI) in group IV was $25.3 \pm 1.1$ while the BMI in group II $24.2 \pm 2.7$ and that of control group III was $26.1 \pm 4.2$ and that of control group I was 24.8 \pm 4.7 . The menstrual irregularities in group IV (IDDM) >32 years were $30 \%$ while in group II (IDDM) $\leq 32$ years were $20.0 \%$ and that of control group III were $5 \%$ compared with $0 \%$ group I 
Table (1): Clinical characteristics of women with IDDM and control women.

\begin{tabular}{|c|c|c|c|c|}
\hline & $\begin{array}{c}\text { Control } \leq \mathbf{3 2} \\
\text { (group I) }\end{array}$ & $\begin{array}{c}\text { DMI } \leq 32 \\
\text { (group II) }\end{array}$ & $\begin{array}{c}\text { Control> 32 } \\
\text { (group III) }\end{array}$ & $\begin{array}{c}\text { DMI >32 } \\
\text { (group IV) }\end{array}$ \\
\hline \hline $\mathbf{N}$ & $\mathbf{1 2}$ & $\mathbf{2 0}$ & $\mathbf{8}$ & $\mathbf{1 0}$ \\
\hline Age (years) & $29.2 \pm 7.8$ & $21.8 \pm 4.0$ & $37.4 \pm 3.9$ & $36.2 \pm 3.7$ \\
\hline $\begin{array}{c}\text { Gynecological age } \\
\text { (years) }\end{array}$ & $13.0 \pm 3.5$ & $10.2 \pm 3.2$ & $24.1 \pm 3.2$ & $23.9 \pm 3.4$ \\
\hline $\begin{array}{c}\text { Age at menarche } \\
\text { years }\end{array}$ & $12.8 \pm 1.6$ & $12.4 \pm 1.5$ & $13.1 \pm 1.6$ & $13.2 \pm 1.4$ \\
\hline BMI Kg/m2 & $24.8 \pm 4.7$ & $24.2 \pm 2.7$ & $26.1 \pm 4.2$ & $25.3 \pm 1.1$ \\
\hline $\begin{array}{c}\text { Menstrual cycle } \\
\text { day }\end{array}$ & $28.6 \pm 2.3$ & $32.5 \pm 11.4$ & $28.3 \pm 1.7$ & $33.4 \pm 4.2$ \\
\hline $\begin{array}{c}\text { Menstrual } \\
\text { irregularity }\end{array}$ & $0 \%$ & $20 \%$ & $5 \%$ & $30 \%$ \\
\hline
\end{tabular}

Table (2): Comparison between the studied groups as regard F.S.H.

\begin{tabular}{|c|c|c|c|c|}
\hline & $\begin{array}{c}\text { FSH } \\
\text { mIU/ML }\end{array}$ & $\begin{array}{c}\text { FSH } \\
\text { mIU/ML }\end{array}$ & FSH mIU/MI & FSH IU/ML \\
\hline & $\begin{array}{c}\text { Group I } \\
\text { Control } \leq \mathbf{3 2} \\
\mathbf{n = 1 2}\end{array}$ & $\begin{array}{c}\text { Group II } \\
\text { Patient } \leq \mathbf{3 2} \\
\mathbf{n = 2 0}\end{array}$ & $\begin{array}{c}\text { Group III } \\
\text { Control } \\
\mathbf{> 3 2} \mathbf{~ n = 8}\end{array}$ & $\begin{array}{c}\text { Group IV } \\
\text { Patient }>\mathbf{3 2} \\
\mathbf{n = 1 0}\end{array}$ \\
\hline Mean & 5.39 & 6.39 & 8.94 & 10.1 \\
\hline SD & 0.66 & 2.18 & 2.28 & 2.54 \\
\hline Min & 4.5 & 3.5 & 5.5 & 7.5 \\
\hline Max & 6.5 & 11 & 13 & 15.6 \\
\hline P value & \multicolumn{2}{|c|}{0.141} & \multicolumn{2}{|c|}{0.192} \\
\hline
\end{tabular}




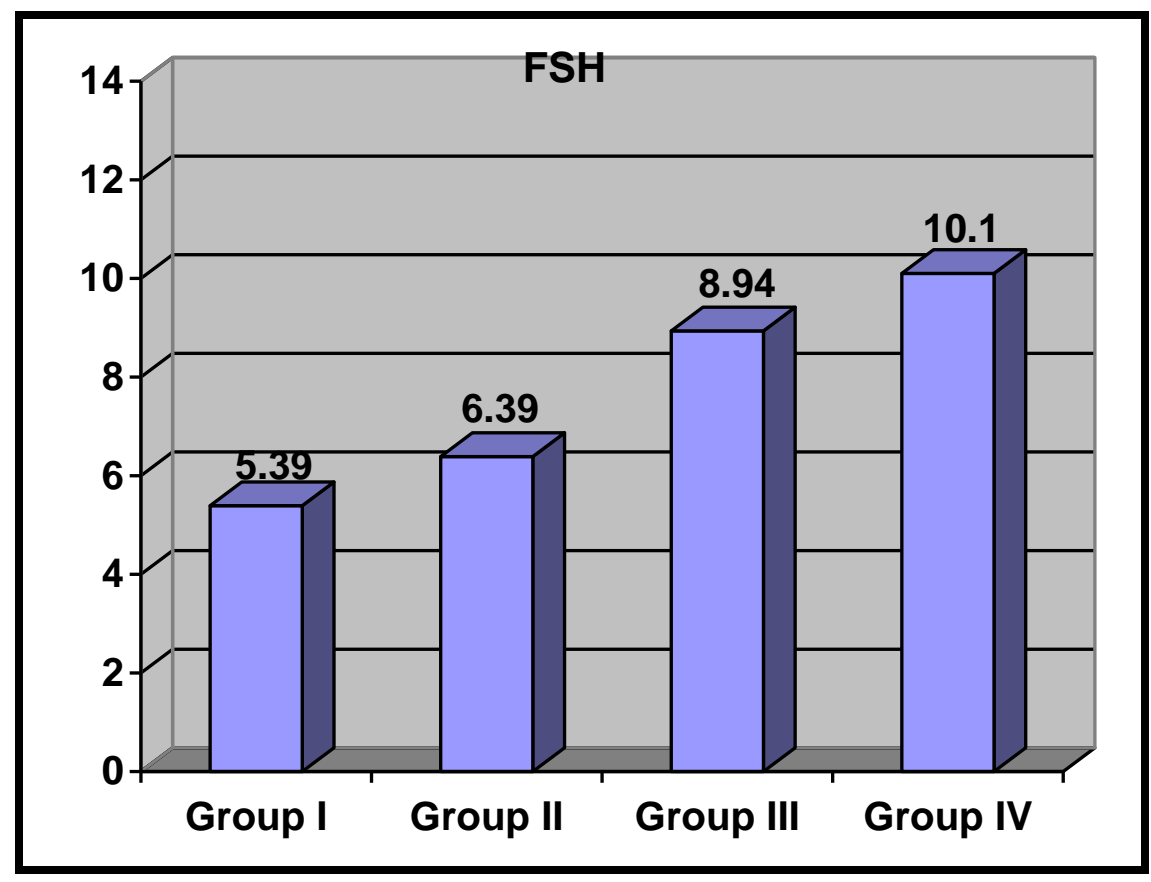

F.S.H in IDDM > $32 \mathrm{Y}$ group IV IDDM $\leq 32 \mathrm{Y}$ group II as compared to Control groups.

Table (3): Comparison between the studied groups as regard LH.

\begin{tabular}{|c|c|c|c|c|}
\hline & $\begin{array}{c}\text { LHmIU/ML } \\
\text { Control } \mathbf{3 2} \\
\mathbf{n = 1 2}\end{array}$ & $\begin{array}{c}\text { LHmIU/ML } \\
\text { Patient } \mathbf{3 2} \\
\mathbf{n = 2 0}\end{array}$ & $\begin{array}{c}\text { LHmIU/MIL } \\
\text { Control }>\mathbf{3 2} \mathbf{n}=\mathbf{8}\end{array}$ & $\begin{array}{c}\text { LHmIU/ML } \\
\text { Patient }>\mathbf{3 2} \\
\mathbf{n = 1 0}\end{array}$ \\
\hline Group I & Group II & Group III & Group IV \\
\hline Mean & 4.50 & 6.40 & 8.89 & 6.38 \\
\hline SD & 2.43 & 3.29 & 2.60 & 2.43 \\
\hline Min & 1 & 1.3 & 4.88 & 1.5 \\
\hline Max & 9 & 11.5 & 11.5 & 10 \\
\hline P value & \multicolumn{2}{|c|}{0.085} & \multicolumn{2}{|c|}{0.045} \\
\hline
\end{tabular}

Comparing the mean \pm SD levels of F.S.H among groups revealed no significant difference in the mean \pm SD levels among the (IDDM) and control groups $>$ or $\leq 32$ years. Comparing the mean \pm SD levels of $\mathrm{LH}$ among groups revealed no significant difference in the mean \pm SD of LH among

(IDDM)

and

control

groups

( $\mathrm{P}>0.05)$. 


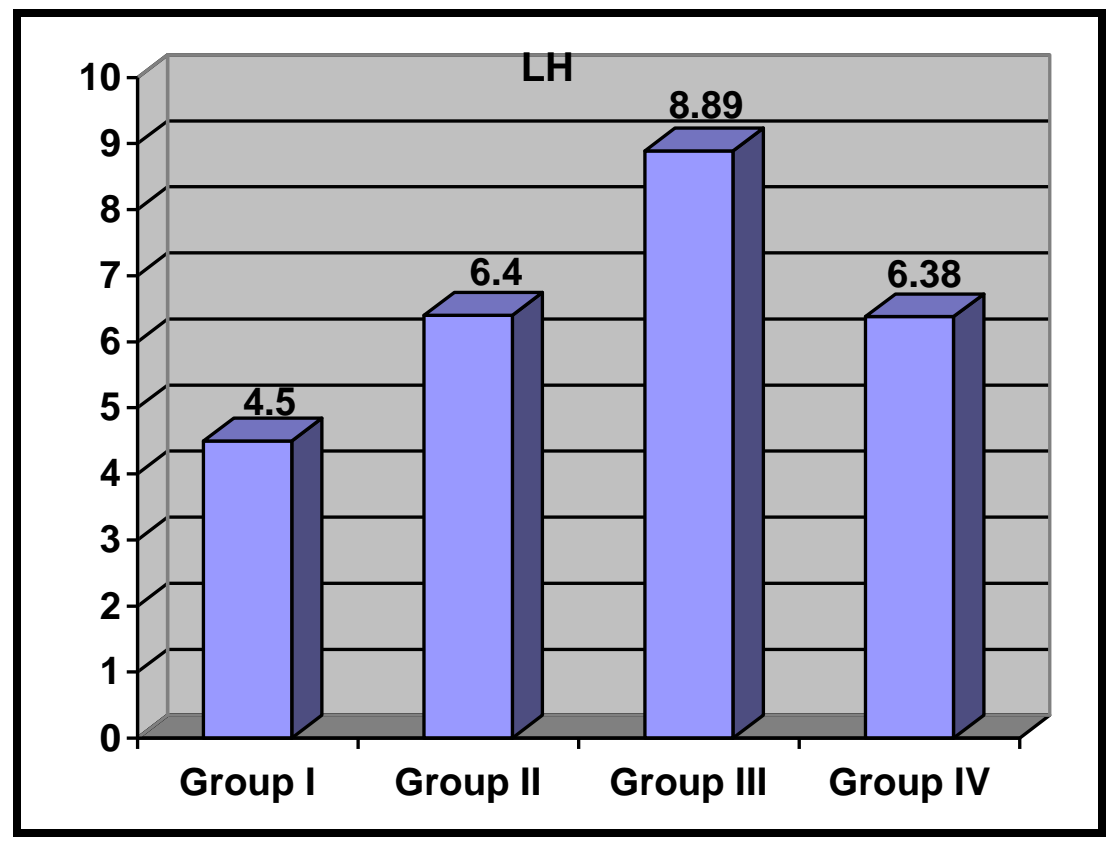

LH in IDDM > 32 Y group IV and IDDM $\leq 32$ Y group II as compared to control groups.

Table (4): Comparison between the studied groups as regard inhibin B.

\begin{tabular}{|c|c|c|c|c|}
\hline & $\begin{array}{c}\text { Inhibin B pg/ml } \\
\text { Control } \mathbf{3 2} \\
\mathbf{n = 1 2}\end{array}$ & $\begin{array}{c}\text { Inhibin B pg/ml } \\
\text { Patient } \mathbf{3 2} \\
\mathbf{n = 2 0}\end{array}$ & $\begin{array}{c}\text { Inhibin B pg/ml } \\
\text { Control }>\mathbf{3 2} \\
\mathbf{n = 8}\end{array}$ & $\begin{array}{c}\text { Inhibin B pg/ } \\
\text { Patient }>\mathbf{3 2} \\
\mathbf{n = 1 0}\end{array}$ \\
\hline Group I & Group II & Group III & Group IV \\
\hline SD & 28.67 & 50.06 & 65.83 & 21.22 \\
\hline Min & 22.3 & 24.45 & 17.95 & 18.76 \\
\hline Max & 96 & 1.005 & 22 & 8.7 \\
\hline P-value & \multicolumn{2}{|c|}{0.065} & 86 & 78 \\
\hline
\end{tabular}

There was no significant difference in the mean \pm SD of inhibin $B$ in group II (IDDM) $\leq 32$ when compared to group I control group $\leq 32(\mathrm{P}>0.05)$ and there was highly significant decrease in mean \pm SD of inhibin B in group IV (IDDM) $>32 \mathrm{Y}(21.22 \pm 18.7)$ when compared to group III control group $>32 \mathrm{Y}(65.8 \pm 17.9)(\mathrm{P}<0.01)$. 


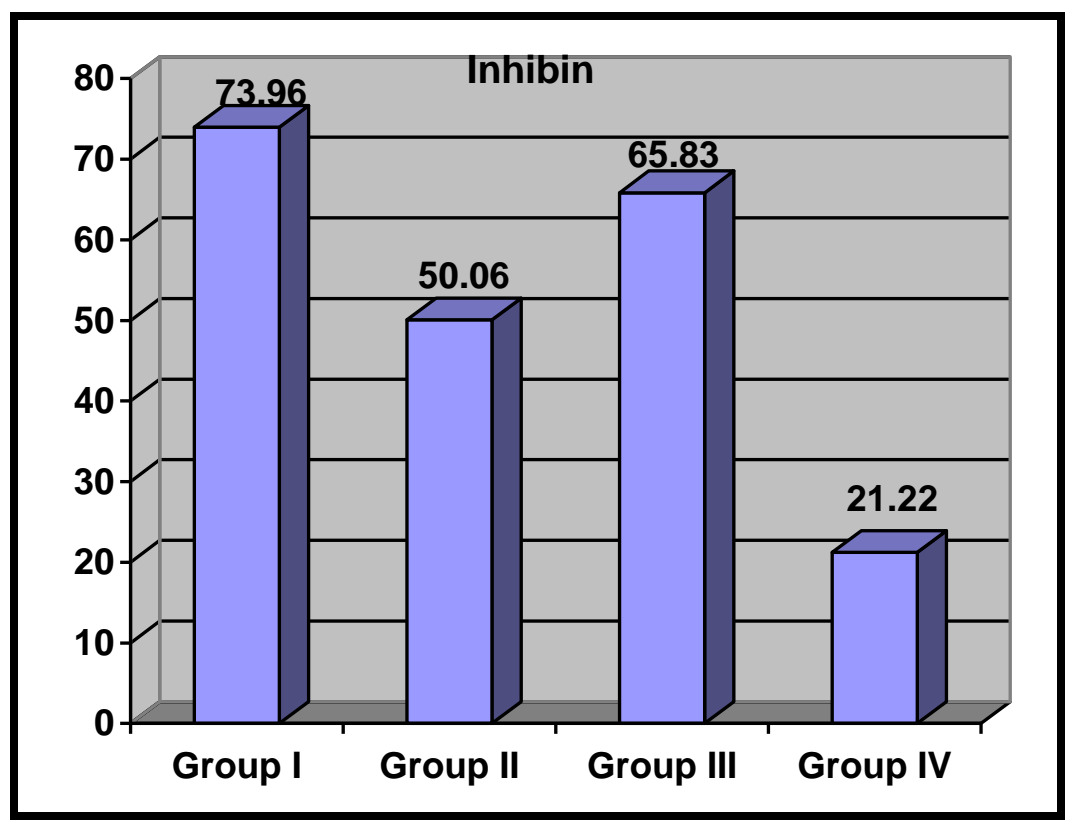

Inhibin B in DDMI > 32Y group IV and DDMI $\leq 32 \mathrm{Y}$ group II as compared to control groups.

Table (5): Comparison between the studied groups as regard AMH.

\begin{tabular}{|c|c|c|c|c|}
\hline & $\begin{array}{c}\text { AMHng/ml } \\
\text { Control } \mathbf{3 2} \\
\mathbf{n = 1 2}\end{array}$ & $\begin{array}{c}\text { AMHng/ml } \\
\text { Patient } \mathbf{3 2} \\
\mathbf{n = 2 0}\end{array}$ & $\begin{array}{c}\text { AMHng/ml } \\
\text { Control }>\mathbf{3 2} \\
\mathbf{n = 8}\end{array}$ & $\begin{array}{c}\text { AMHng/ml } \\
\text { Patient }>\mathbf{3 2} \\
\mathbf{n = 1 0}\end{array}$ \\
\hline & Group I & Group II & Group III & Group IV \\
\hline Mean & 7.88 & 5.81 & 7.79 & 2.35 \\
\hline SD & 9.37 & 2.46 & 1.73 & 2.22 \\
\hline Min & 2.5 & 2.5 & 5.6 & 0.05 \\
\hline Max & 43 & 9.2 & 9.6 & 7.5 \\
\hline P-value & \multicolumn{2}{|c|}{0.396} & & \multicolumn{3}{c|}{0.000} \\
\hline
\end{tabular}

There was highly significant decrease in mean \pm SD of AMH in group IV (IDDM) $>32 \mathrm{Y}$ $(2.35 \pm 2.2)$ when compared to group III (Control group > $32 \mathrm{Y})(7.79 \pm 1.7) \mathrm{P}<0.000)$ and there was no significant difference in mean + SD of AMH level in group II (IDDM $\leq 32 \mathrm{Y}$ ) (5.8 \pm 2.46$)$ when compared to group I (control group $\leq 32 \mathrm{Y})(7.88 \pm 9.37)(\mathrm{P}>0.05)$. 


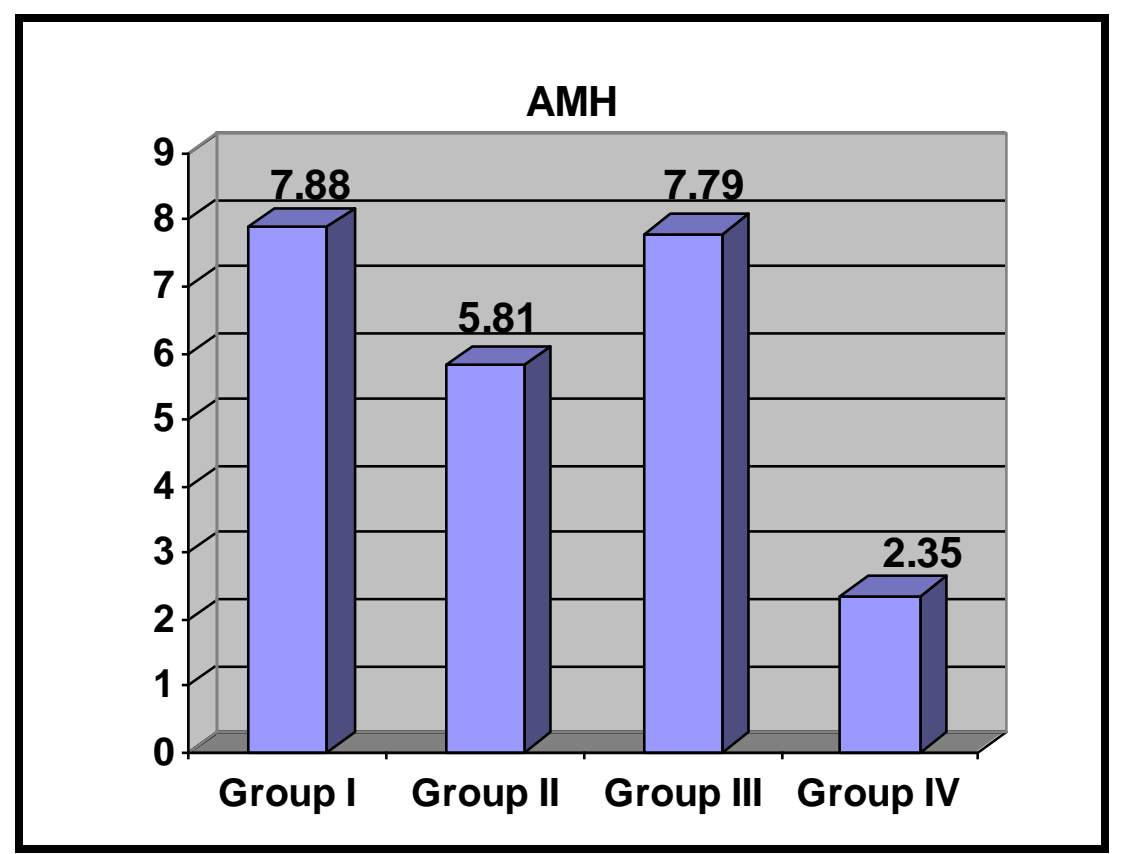

AMH in IDDM $>32 \mathrm{Y}$ group IV and IDDM $\leq 32 \mathrm{Y}$ group II as compared to control groups.

Table (6): Comparison between the studied groups as regard Antral follicle count.

\begin{tabular}{|c|c|c|c|c|}
\hline & $\begin{array}{c}\text { Control } \mathbf{3 2} \\
\mathbf{n = 1 2}\end{array}$ & $\begin{array}{c}\text { Patient } \leq \mathbf{3 2} \\
\mathbf{n = 2 0}\end{array}$ & $\begin{array}{c}\text { Control }>\mathbf{3 2} \\
\mathbf{n = 8}\end{array}$ & $\begin{array}{c}\text { Patient }>\mathbf{3 2} \\
\mathbf{n = 1 0}\end{array}$ \\
\hline & Group I & Group II & Group III & Group IV \\
\hline $\begin{array}{c}\text { AFC No of } \\
\text { follicles in } \\
\text { two ovaries }\end{array}$ & $9.1 \pm 4.3$ & $4.6 \pm 3.2$ & $5.5 \pm 6.5$ & $2.4 \pm 1.5$ \\
\hline$<5 \%$ & $20 \%$ & $60 \%$ & $65 \%$ & $90 \%$ \\
\hline Not visible & $0 \%$ & $15 \%$ & $15 \%$ & $30 \%$ \\
\hline
\end{tabular}

There is statistically significant difference AFC in IDDM groups compared with the control groups $\mathrm{P}<0.01$ 


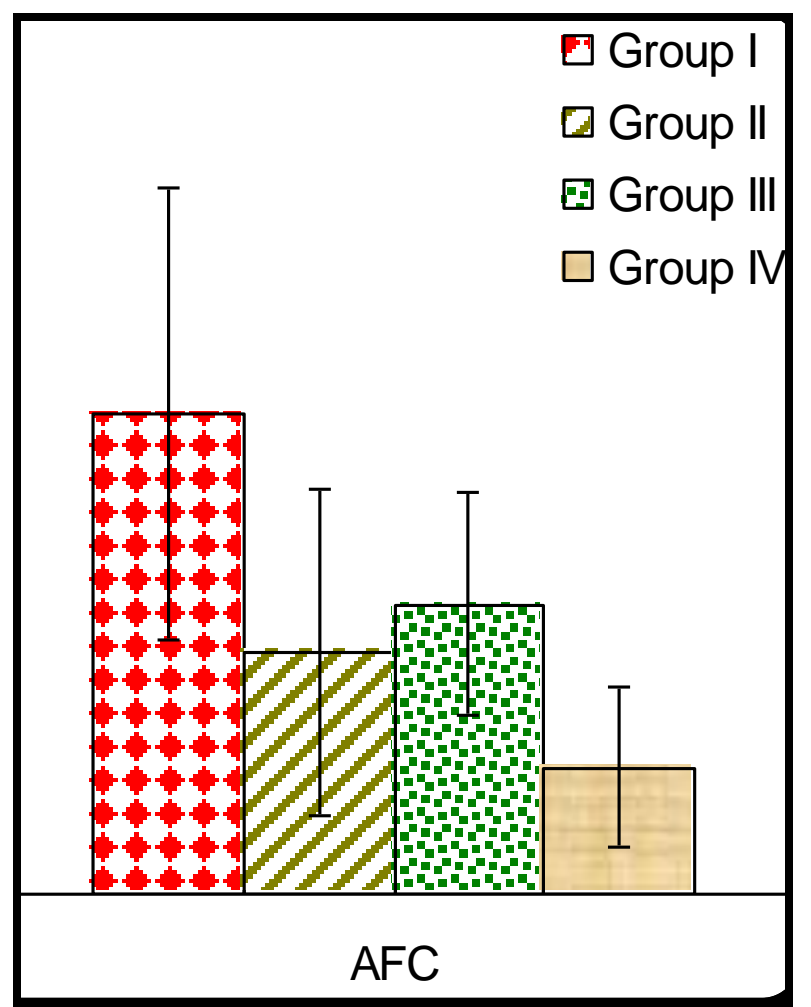

Antral follicle count in DDMI groups compared with control
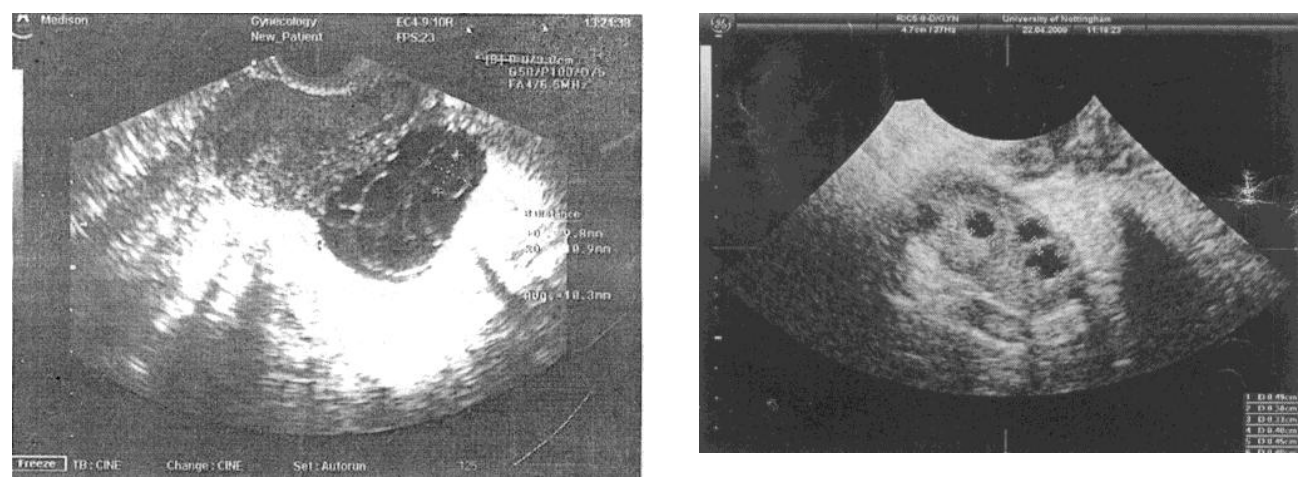

Fig. (1\&2): Transverse/view of the ovary on 2D-US. Each AF is measured by taking the mean of two per pendicular linear measured (calipers)

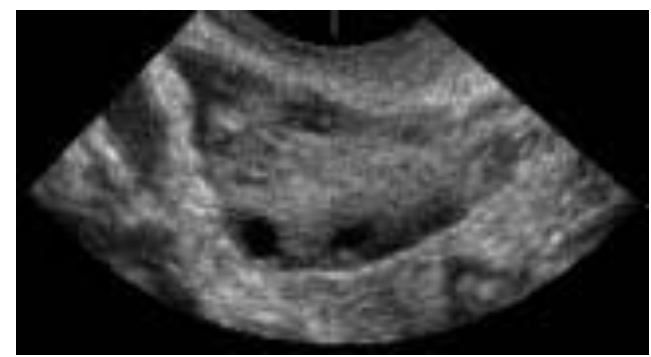

Fig. (3): AFC by 3D 


\section{Discussion}

IDDM have premature ovarian aging: Several mechanisms are involved include elevated levels of vascular endothelial growth factor, apoptosis (Tilly, 2001). Protein damage and a reduced oxygen supply (Taton et al., 2008).

The incidence of menstrual irregularities was higher in the IDDM>32-years (group IV) compared to IDDM $\leq 32$ years (group II). Also cycle length was longer in IDDM $>32$ years (group IV).

Serum AMH levels began to decline 10 years before the final menstrual period however levels of FSH, E2 are normal until a couple of years before the cessation of menses.

AMH determination has been proposed in clinical practice for the prediction of ovarian reserve because it signals pool of inactive and initially growing follicles, it means the stock of primordial follicles (Van Rooij et al., 2005).

The present study showed highly significant decrease of AMH in DMI > 32 years when compared to control group of the same age $\mathrm{P}<0.01$ however there was decrease but not statistically significant difference in $\mathrm{AMH}$ levels in IDDM $\leq 32$ years compared to control group $\leq 32$ years. In agreement with our finding (Soto et al., 2009) reported lower levels of AMH in IDDM women > 33 years of age and similar levels of AMH in IDDM group $\leq 33$ years compared with control group. Also (Van Dissel et al., 2008), reported that AMH levels may predict age at menopause and in women approaching menopause, extremely low AMH levels are observed.

In the present study there is statistically significant decrease in AFC in IDDM groups compared with the control groups $\mathrm{P}<0.01$.

However AFC not visible in $30 \%$ of cases IDDM $>32$ Y.

Also (Sheffer et al., 2003), observed that ultrasonography is not conclusive in $26 \%$ of hypergonadotropic patients because one or both ovaries were not visible.

In agreement with our results Robertson et al. (2008), suggested that $\mathrm{AMH}$ is more consistent than AFC as a measure to assess the extent of the follicle pool this is because on or both ovaries were not visible, Moreover, AFC requires state of the art ultrasound machines and expererienced ultrasonographists (Scheffer et al., 2006).

Circulating levels of FSH are controlled by a negative feedback mechanis on hypothalamus by steroidal hormones. Although days 3 FSH is widely used as an ovarian reserve test, its accuracy in predicting a poor response is adequate only when very high thresholds are used (Broekmans et al., 2006).

In this study we found that the levels of FSH were normal in IDDM>32years while there was decrease in the levels of serum AMH. This can be explained by Broekmans et al. (2006), who reported that the value of FSH usually maintains within normal ranges and tend to rise only when ovarian function is deeply compromised, so its level cannot be used as a criterion of couple exclusion from assisted reproduction cycles.

Inhibin B selectively suppresses the secretion of pituitary FSH and has local paracrine actions in gonads.

The inverse and tight relationship between FSH and inhibin B indicates that inhibin B is a sensitive marker of ovarian follicular competence and play a role in follicular development (Ramalho et al., 2008).

Tsigkou et al. (2008), suggested that increase in inhibin B should sign an autoimmune etiology for ovarian insufficiency as a result of precocious thecal destruction with preservation of granulose cells.

The present study showed lower levels of inhibin B in IDDM groups compared with the control groups. This decrease was statistically significant in IDDM >32years. This findings suggest poor ovarian reserve and a lower number of antral follicles in these patients. Also this lower levels of inhibin B exclude autoimmune oophritis as a cause of premature ovarian failure.

Our results also showed that AMH levels and inhibin B levels decrease earlier in women with IDDM and they are better predictor of ovarian reserve than AFC. 


\section{References}

Bancsi LF, Broekmans FJ, Looman CW, Habbema JD, Te velde ER (2004): Impact of repeated antral follicle counts on the prediction of poor ovarian response in women undergoing in vitro fertilization fertile Steril 81: 35-41.

Broekmans FJ, Kwee J, Hendriks. DJ, Mol BW, Lambak CB (2006): Asystematic review of tests predicting ovarian reserve and IVF out come.Hum Reprod update 12:685-718.

Burger HG, Hale GE, Roberson DM, Dennerstein L (2007): A review of hormonal changes during the menopausal transition: Focus on findings from the Melbourne women's midlife Health Project. Hum Reprod.update, 13:559-565.

Conder E, Cassorla F (2009): Puberty and ovarian function in girls with type I diabetes mellitus. Horm Res 71:12-21.

Coulman CB, Adamson SG, Annegers JF (1986): Incidence of premature ovarian failure Obstet Gynecol 67:604-606.

Faddy MJ, Gosden RG (1996): A model conforming the decline numbers to the age of menopause in women. Hum Reprod 11: 14841486.

Freeman E W, Sammel MD, Garacia CR, Kapoors, Lin. H, LiuL, Nelson DB (2005): Follicular phase hormone levels and menstrual bleeding status in the approach to menopause fertile-steril 83:383-392

Martin KA, Manson JE (2008): Approach to the patient with menopausal symptoes. J Clin Endocrinol Metab; 93, 4567-4575.

Mary Fran R, Sowers, Huiyong Zheng, Daniel McConnell, Bin Nan, Si oban D.Hariow and John F, Randolph, Jr (2008): Estradiol rates of change in relation to the final menstrual period in a population-Based cohort of women. J.Clin Endocrinol Metab, 10:38473852.

Ramalho B. de Carvalho, Ana Carolina, Japur desa Rosa esilva, et al. (2008): Ovarian reserve evaluation state of the art.Human reproduction. Reviced.

Robertson DM, Hale GE, Fraser JS, Hughes CL, Burger HG (2008): A Proposed classification system for menstrual cycles in the menopause transition based on changes in serum hormone profiles. Menopause 15: 11391144.

Scheffer GJ, Broekmans FJ, Looma CW, Blankevstein M, Fouser BC et al. (2003): The number of antral follicles in normal women with proven fertility is the best reflection of reproductive age. Hum reprod 18: 700-760.
Scheffer GJ, Broekmans FJM, Dorlandm, Habbema JDF (1999): Antral follicle counts by transvaginal ultrsonography are related to age in women with proven natural fertility. Fertil steril 72: 845-851.

Snell-Bergeon JK, Dabelea, Dogden LG, Hokanson JE, Kinney GL, Ehrlich J, Rewers M (2008): Reproductive history and hormonal birth control use are associated with coronary calcium progression in women with type I diabetes mellitus. J.Clin. Endocrinol Metab; 93:2142-2148

Soto N, German Jniquez, Patricia Lopez, Gladys Larenas, et al. (2009): Anti-Mullerian hormone and inhibin B levels as markers of premature ovarian aging and transition to menopause in type I diabetes mellitus. Human reproduction, 24 (11): 2838-2844.

Sowers MR, Eyvazza deh AD, Me Connell D, Yosef MJ Jannausch ML, Zhang D, Harlow S, Randol ph JF Jr (2008): Antimullerian hormone and inhibin $\mathrm{B}$ in the definition of ovarian aging and the menopause transition. $\mathrm{J}$ Clin Endocrinol Metab; 93:3478-3483.

Tatone C, Amicarellif, carbone M, Monteteone P, Caserta D, Marcir, Arunip, Piombonip, Focarelli R (2008): Cellular and molecular aspects of ovarian follicle aging.Hum. Reprod. Update; 14:131-142.

Tilly JL. (2001): Commuting the death sentence, how oocytes strive to survive. Mol. Cell Biol; 2: 883-848.

Tsigkon A, Marzottis, Borgesl, Brozzetti A, Reisf, Candeloro. P, et al. (2008): High serum inhibin concentration discriminates outoimmunne oophoritis from other forms of primary ovarian insufficiency. J.Clin Endocrinol.Metab; 93 (4): 1263-9.

Van Disseldrop J, Faddy MJ, Themmen AP, de Jong FH, Peeters PH, Van der Schouw YT, Broekmans FJ (2008): Relationship of Serum antimullerian hormone concentration to age at menopause. J Clin: Endocrinol Metab 43:2129-2134

Van Rooij JA Tonkelaar J, Brcoekmans FJ, Looman CW, scheffer GJ, de Jong FH, themmen AP, tevelde ER (2004): Antimullerian hormone is apromising predectorfor the occurance of the menopausal transition.Menopause 11: 601-606.

Van Rooij, Broekmans FJ, Scheffer GJ, Looman Cw, Habbewa JD, de Jong FH, Fauser BJ, Themmen AP, Te velde ER (2005): Serum antimullerian hormone levels best reflect the reproductive decline with age in normal women with proven fertility. Alongitudinal study fertile steril 83:979-987. 


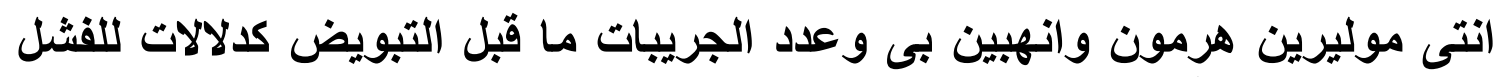

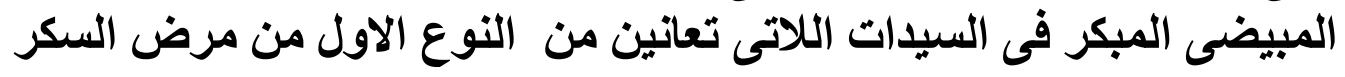

النثيماء علام عبداللطيف* صباح ابراهيم عبد الرحيم** امانى محمدالسعيد عبد

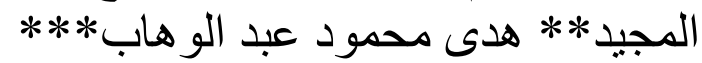

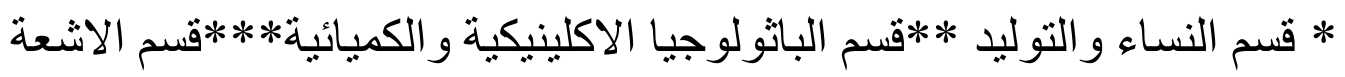
كلية طب بنات جامعة الاز هر

اجرى هذا البحث لقياس مستوى انتى موليرين هرمون و انهبين بى فى السيدات الاتى

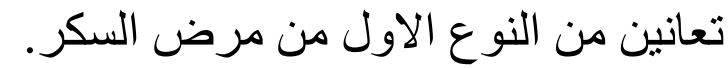

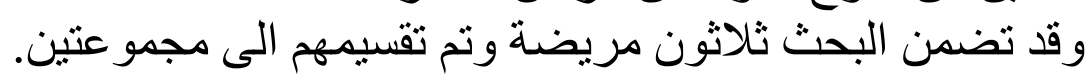

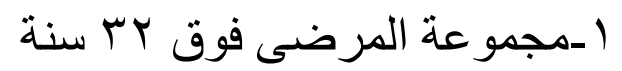

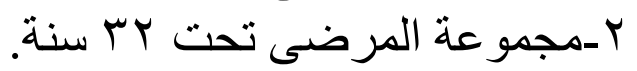

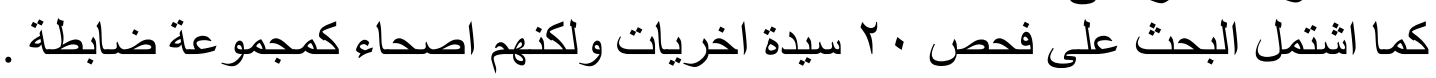
وقد تم قياس مستوى اف اس اتش و الت الت الت ومستوى كلا من انتى موليرين هرمون

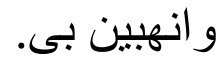
وقد اوضحت النتائج ان مستوى الانهبين كان منخفضا احصائيا فى كلتا المجمو عتين

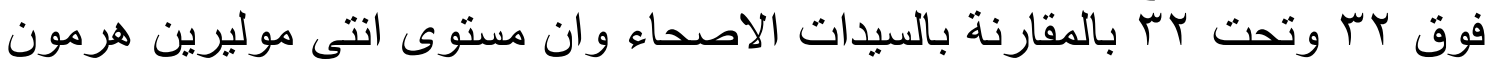

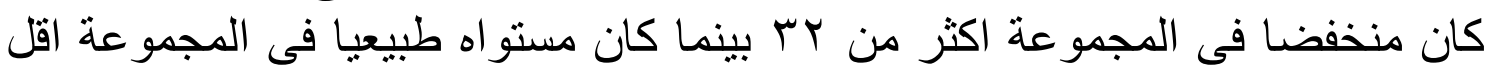

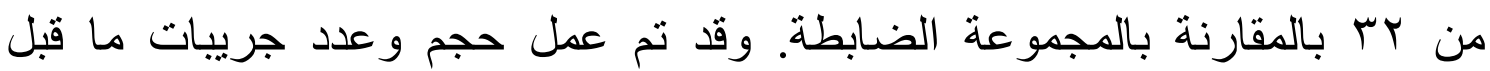

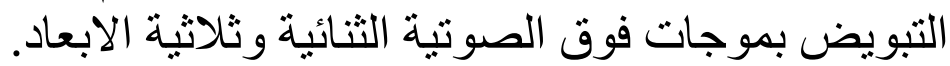

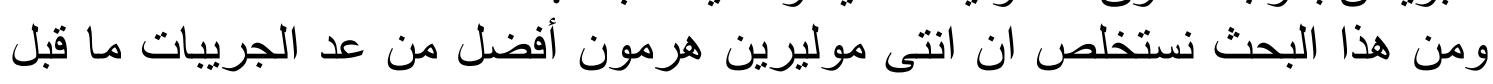

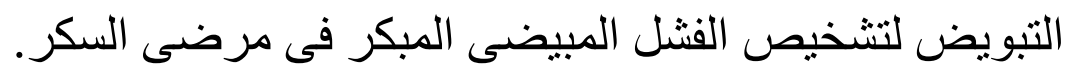

